University of Nebraska - Lincoln

DigitalCommons@University of Nebraska - Lincoln

Germination and Emergence Tests for Predicting Switchgrass Field Establishment

\author{
Robert B. Mitchell \\ USDA-ARS, rob.mitchell@ars.usda.gov \\ K. P. Vogel \\ USDA-ARS, kvogel1@unl.edu
}

Follow this and additional works at: https://digitalcommons.unl.edu/usdaarsfacpub

Part of the Agricultural Science Commons

Mitchell, Robert B. and Vogel, K. P., "Germination and Emergence Tests for Predicting Switchgrass Field Establishment" (2012). Publications from USDA-ARS / UNL Faculty. 1087.

https://digitalcommons.unl.edu/usdaarsfacpub/1087

This Article is brought to you for free and open access by the U.S. Department of Agriculture: Agricultural Research Service, Lincoln, Nebraska at DigitalCommons@University of Nebraska - Lincoln. It has been accepted for inclusion in Publications from USDA-ARS / UNL Faculty by an authorized administrator of DigitalCommons@University of Nebraska - Lincoln. 


\title{
Germination and Emergence Tests for Predicting Switchgrass Field Establishment
}

\author{
R. B. Mitchell* and K. P. Vogel
}

\begin{abstract}
The effect of switchgrass (Panicum virgatum L.) seed quality tests on field establishment has been addressed inadequately. Our objective was to evaluate the ability of seed quality tests to predict field establishment. Standard Association of Official Seed Analysts (AOSA) tests are based on the percentage of seeds in a seedlot that germinate under standard laboratory conditions, whereas the seedlot establishment tests (SETs) are based on the number of seeds that emerge per gram of seed using different germination or stress test conditions. The SET was determined using six laboratory tests and the results validated in three replicated field trials. Treatments were: (i) AOSA pure live seed (PLS) test assuming $858 \mathrm{seeds}^{-1}$; (ii) AOSA test with no prechill; (iii) AOSA test with prechill; (iv) heat stressed at $50^{\circ} \mathrm{C}$ for $12 \mathrm{~h}$; (v) emergence from $4 \mathrm{~cm}$ of sand; and (vi) heat stressed plus emergence from $2 \mathrm{~cm}$ of sand. Data from noncontrol tests were on a SET per-gram basis. Field establishment differed by the seed quality test on which the seeding rate was based. The best predictor of field establishment was emergence from $4 \mathrm{~cm}$ of sand, which had an establishment index (ratio of field-emerged seeds to seeds planted) that was 3.5 times greater than the PLS method and $36 \%$ greater than no prechill. Stands on which planting rates were based on SET that included stress tests were better predictors of field establishment than the standard PLS method. Switchgrass seeding rates based on SET are recommended to reduce the risk of failure during stand establishment.
\end{abstract}

$S^{w}$ WITCHGRASS IS AN important warm-season grass for use as a potential bioenergy crop in the United States on marginal cropland (Vogel, 2004). Switchgrass, a native perennial, can be highly productive in most rainfed production systems east of the 100th meridian. On marginal cropland, it can reduce erosion, increase $\mathrm{C}$ sequestration, and increase crop and wildlife diversity compared with row crops (McLaughlin and Walsh, 1998; Sanderson et al., 1996; McLaughlin and Kszos, 2005; Mitchell et al., 2008). The economic viability of growing switchgrass for bioenergy hinges on successful stand establishment in the seeding year (Perrin et al., 2008). A seeding-year goal for switchgrass is uniform, successful establishment followed by a post-frost biomass harvest equivalent to $50 \%$ of the yield potential of the cultivar when fully established, with full yield potential achieved in Year 2 (Mitchell et al., 2008). We have achieved these results in research plots, pastures, and several on-farm trials during a 20-yr period (Vogel et al., 1981; Vogel, 1987; Anderson et al., 1988; Hopkins et al., 1993; Perrin et al., 2008) by using high-quality seed, herbicides for weed control, and a set of establishment practices that we recommend (Mitchell et al., 2010a). Poor stands can result in the need for replanting or reduced biomass yields for one or

R.B. Mitchell and K.P. Vogel, USDA-ARS Central East Regional Biomass Center, Grain, Forage and Bioenergy Research Unit, Dep. of Agronomy and Horticulture, Univ. of Nebraska, Lincoln, NE 68583. Received 2 Jun. 2011. *Corresponding author (rob.mitchell@ars.usda.gov).

Published in Agron. J. 104:458-465 (2012)

Posted online 27 Jan. 2012

doi:10.2134/agronj2011.0168

Available freely online through the author-supported open access option.

Copyright (c) 2012 by the American Society of Agronomy, 5585 Guilford Road, Madison, WI 53711. All rights reserved. No part of this periodical may be reproduced or transmitted in any form or by any means, electronic or mechanical, including photocopying, recording, or any information storage and retrieval system, without permission in writing from the publisher. more years until stand density increases by established plant tillering (Schmer et al., 2006). The main causes of poor or failed switchgrass establishment are lack of rainfall during the establishment period, weed competition due to poor weed control practices, improper planting procedures including seedbed preparation and planting depth, and poor seed quality. All factors except rainfall can be addressed by management.

Several decades of empirical research has resulted in improved grass drills for no-till or minimum-till establishment of switchgrass along with associated optimal seedbed preparation procedures (Mitchell et al., 2010b). Research on switchgrass seedling morphology and development has provided a clear scientific basis for the need for shallow seeding depths of about $1 \mathrm{~cm}$ in firm seedbeds (Newman and Moser, 1988; Vogel, 2004). Likewise, research on herbicides to control weeds during establishment has resulted in the labeling of herbicides for pre- or post-emergence on newly established switchgrass fields that can significantly reduce weed competition and improve establishment (Martin et al., 1982; Vogel, 1987; Masters et al., 1996; Mitchell et al., 2010a). The use of a frequency grid to quickly and effectively monitor the establishment of switchgrass and other grasses was used in the herbicide research and has become widely accepted, with 60 citations to date since its publication (Vogel and Masters, 2001). In previous switchgrass establishment research, frequency-grid-measured switchgrass stands of 40 to $50 \%$ or greater indicated a successful stand, stand frequencies from 25 to $50 \%$ were marginal to adequate, and stands with frequencies $<25 \%$ indicated partial stands that need replanting (Vogel, 1987; Schmer et al., 2006). In many cases, poor stand establishment that requires replanting is due to poor seed quality.

Abbreviations: AOSA, Association of Official Seed Analysts; PLS, pure live seed; SET, seedlot establishment test. 
The effect of switchgrass seed quality on field establishment as measured by different quality tests has not been addressed; however, the importance of seed quality on establishment is recognized because of problems observed with some of our switchgrass seedlots in field trials. Despite decades of experience in establishing switchgrass, we have had some seedlots that failed to become well established even though they had germination equivalent to seedlots that produced acceptable stands. The economic costs to farmers for a stand failure due to poor quality seed would exceed US $\$ 300 \mathrm{ha}^{-1}$ (Perrin et al., 2008). The AOSA rules for testing switchgrass and other grass seedlots consist of a purity test and a germination test (Association of Official Seed Analysts, 2010a). The germination test is reported as the percentage of seeds germinated under AOSAprescribed conditions, which include a 2 -wk moist prechill at $5^{\circ} \mathrm{C}$ followed by a 2 -wk germination period with alternating temperatures of $15^{\circ} \mathrm{C}(16 \mathrm{~h})$ and $30^{\circ} \mathrm{C}(8 \mathrm{~h})$, with light during the 8 -h period. Purity is determined on a mass basis (pure seed weight/seedlot weight) and is reported as a percentage. Switchgrass seed is sold on a pure live seed (PLS) basis calculated as

$$
\begin{aligned}
& \operatorname{PLS}(\%)= \\
& \frac{\text { seedlot purity }(\%) \times \text { germination }(\%)}{100}
\end{aligned}
$$

Some switchgrass seedlots can have significant dormancy for a year or more after harvest (Vogel, 2004). The 2-wk moist prechill treatment in the AOSA germination standards breaks dormancy and can be combined with $\mathrm{KNO}_{3}$ treatment, which can aid in breaking seed dormancy. Other chemicals such as peroxide can break switchgrass seed dormancy and improve germination, but, to date, these treatments have been confined to laboratory evaluation only (Sarath and Mitchell, 2008). A tetrazolium test can be used after the germination test to determine if any of the ungerminated seeds are viable (Association of Official Seed Analysts, 2010b). Seeds shown to be viable by the tetrazolium test can be included in PLS. Seeding rate recommendations for perennial grasses such as switchgrass are currently determined on a PLS basis (Cosgrove and Collins, 2003).

The AOSA seed quality test for switchgrass measures germinated and viable seeds and seedlot purity. It is a reliable and effective test for those seedlot attributes. It does not measure seedling vigor of the germinated seeds, however, and it includes some seeds that germinate under the conditions of the germination test and associated pretreatments but may not germinate under field conditions due to seed dormancy. Switchgrass has a $\mathrm{C}_{4}$ photosynthetic pathway, so the germination and growth of seedlings are reduced at temperatures below $20^{\circ} \mathrm{C}$ (Vogel et al., 2010). Recommended switchgrass planting dates in a region are similar to those for maize (Zea mays L.), which means soil temperatures probably will be too warm to help break seed dormancy. There are some inherent problems in using PLS to determine seeding rates because the number of seeds per gram for switchgrass can vary by $>40 \%$ even for seedlots of the same cultivar (Vogel, 2002), and reported PLS can include dormant seed whose dormancy was broken by the prechill protocol in the germination test. Although germination and purity percentages must be reported on switchgrass seed tags, the number of seeds per gram is not. The recommended seeding rate for switchgrass in the Great Plains is 300 to $400 \mathrm{PLS} \mathrm{m}^{-2}$ (Mitchell et al., 2010b), but successful stands can be established with seeding rates as low as $100 \mathrm{PLS} \mathrm{m} \mathrm{m}^{-2}$ if quality seed is used (Vogel, 1987). To effectively use the PLS information on a switchgrass seed tag, the number of seeds per gram or kilogram must be known. Producers can count the number of seeds per gram, but this is rarely done when planting production fields. Instead, a standard book value for the number of seeds per kilogram (i.e., 850,000 seeds $\mathrm{kg}^{-1}$ for switchgrass) is used (Wheeler and Hill, 1957). The amount of seed to plant for a seedlot $(\mathrm{kg}$ $\left.\mathrm{ha}^{-1}\right)=\left[\left(\right.\right.$ seeds $\left.\mathrm{m}^{-2} \times 10,000 \mathrm{~m}^{2} \mathrm{ha}^{-1}\right) /\left(\right.$ no. of seeds kg $\left.\left.{ }^{-1}\right)\right] /$ PLS. In this equation, PLS is expressed as a decimal and a standard number of seeds per kilogram is used for the number of seeds. Unless the number of seeds per kilogram is the same as the standard, the actual planting rate in seeds per square meter will be different from the calculated planting rate. Including the actual number of seeds per kilogram on the seed tag would improve seeding accuracy with the PLS method. Significant amounts of dormant seed in the PLS percentage result in additional seeding rate errors.

The objective of the present study was to evaluate different seed quality tests for their ability to be predictive of actual field establishment to reduce the risk of catastrophic failure during switchgrass stand establishment. To differentiate the tests we evaluated from the standard AOSA tests, the tests are described as seedlot establishment tests (SETs). Because grassland drills need to be calibrated using kilograms per hectare and because the number of switchgrass seeds per gram varies widely, for the SET evaluation we used the number of seeds germinated or emerged per gram of seed as our measure of seed quality. This eliminates errors due to seed size differences among seedlots when calculating planting rates. Functionally, a SET is the PLS for a seedlot based on the number of seeds per gram for that specific seedlot; however, a SET differs from PLS in that the SET does not credit the seedlot for dormant seed and only accounts for germinable or emerging seeds. Our working hypothesis was that seeding switchgrass based on SET evaluations will increase the ability to reliably establish switchgrass stands compared with existing practices, regardless of the quality of different seedlots.

\section{MATERIALS AND METHODS}

There were two research phases. The first phase consisted of the germination chamber and greenhouse experiments and the second phase was the field trials, which tested the effectiveness of the different SET methods. Within a year, all seedlots were first evaluated in Phase 1 to determine germination and emergence rates. In Phase 2, field experiments were planted using treatmentspecific seeding rates based on Phase 1 data. In Phase 1, germination chamber and greenhouse experiments were conducted in Lincoln, NE, in 2002 and 2003 (Table 1). In Phase 2, field experiments were seeded near Mead, NE, in 2002 (Site 1: $41^{\circ} 9^{\prime} 37.74^{\prime \prime}$ N, $96^{\circ} 24^{\prime} 39.54^{\prime \prime} \mathrm{W}$ ) and 2003 (Sites 2 and 3: $41^{\circ} 9^{\prime} 15.24^{\prime \prime} \mathrm{N}$, $\left.96^{\circ} 25^{\prime} 10.24^{\prime \prime} \mathrm{W}\right)$ and monitored for two growing seasons after planting to assess switchgrass establishment and biomass production. A total of 19 switchgrass seedlots from four cultivars (CaveIn-Rock, Shawnee, Sunburst, and Trailblazer) were exposed to five seed quality tests (2-6) in 2002 and six seed quality tests (1-6) in 2003 (Table 1). Seedlots were grown by us, purchased 


\begin{tabular}{|c|c|}
\hline Set & Protocol \\
\hline Pure live seed (PLS) & $\begin{array}{l}\text { standard PLS test (germination } \times \text { purity) following Association of Official Seed Analysts (AOSA) rules for testing } \\
\text { seeds with prechill using published number of } 858 \text { seeds } g^{-1}\end{array}$ \\
\hline No prechill (NP) & SET-germinated seeds per gram for each seedlot using AOSA rules for testing seeds with no prechill \\
\hline Prechill (P) & SET-germinated seeds per gram for each seedlot using AOSA rules for testing seeds with prechill \\
\hline Heat stress $(\mathrm{H})$ & $\begin{array}{l}\text { SET-germinated seeds per gram for each seedlot using AOSA rules for testing seeds with no prechill following a heat } \\
\text { stress treatment }(0.25 \mathrm{~g} \text { of seed placed on top of two layers of dry blotter paper in open germination boxes and kept in } \\
\left.\text { a dark germination cabinet [ } 95 \% \text { relative humidity, } 50^{\circ} \mathrm{C} \text { ] for } 12 \mathrm{~h}\right)\end{array}$ \\
\hline $\begin{array}{l}\text { Emergence through } 4 \mathrm{~cm} \\
\text { of sand (E4) }\end{array}$ & $\begin{array}{l}\text { SET emerged seedlings } 2 \mathrm{I} d \text { after planting } 0.25 \mathrm{~g} \text { of seed } 4 \mathrm{~cm} \text { deep in sand in germination trays drenched with captan } \\
\left(\mathrm{Ig} \mathrm{\textrm {L } ^ { - 1 }} \mathrm{H}_{2} \mathrm{O}\right) \text { and watered daily; sand particle size was } 10 \% \text { coarse }(0.5-1.0 \mathrm{~mm}), 40 \% \text { medium }(0.25-0.5 \mathrm{~mm}), 40 \% \text { fine } \\
(0.10-0.25 \mathrm{~mm}) \text {, and } 10 \% \text { very fine }(0.05-0.10 \mathrm{~mm})\end{array}$ \\
\hline $\begin{array}{l}\text { Heat }+ \text { emergence through } 2 \\
\mathrm{~cm} \text { of sand }(\mathrm{H}+2)\end{array}$ & $\begin{array}{l}\text { combination of heat stress procedure combined with emergence through } 2 \mathrm{~cm} \text { of sand; emerged seedlings counted after } \\
2 \mathrm{l} d \text { to determine emerged seedlings per gram }\end{array}$ \\
\hline
\end{tabular}

from commercial seed growers, or supplied by other switchgrass researchers. Seedlots were stored at $4^{\circ} \mathrm{C}$ and $20 \%$ relative humidity until testing. The germination chamber and greenhouse phase was completed during winter and the field phase occurred within 3 mo of the germination evaluation. Only Seed Lot 12169 was used in both years of the trials. The six seed quality tests were: PLS test (Association of Official Seed Analysts, 2010a,b) (1); germination test with no prechill (NP) (2); germination test with prechill $(\mathrm{P})(3)$; heat stress $(\mathrm{H})(4)$; emergence through $4 \mathrm{~cm}$ of sand (E4) (5); and heat stress plus emergence through $2 \mathrm{~cm}$ of sand $(\mathrm{H}+2)(6)$. Details are shown in Table 1.

All germination chamber and greenhouse seed quality tests for germinating or emerging seeds per gram were replicated six times and were repeated for each planting date. To put the SETs on a similar number of seeds basis as the AOSA germination tests, $0.25 \mathrm{~g}$ of seed was used in the SET germination and emergence tests as the experimental unit and was converted to seeds per gram by multiplication. Data from all tests were used to determine seeding rates on a SET per gram (no. of germinable or emerging seeds $\mathrm{g}^{-1}$ ) basis, except the PLS test in 2003, which assumed 858 seeds $\mathrm{g}^{-1}$. Germination boxes for prechilling treatments were refrigerated at $5^{\circ} \mathrm{C}$ for $14 \mathrm{~d}$. The day before the prechill boxes were scheduled to come out of refrigeration, the heat stress procedure was initiated so all seedlot treatments would finish on the same day. All seedlots tested with the PLS, NP, P, and $\mathrm{H}$ treatments were germinated in a Conviron G30 germinator (Conviron, Winnipeg, MB, Canada). All seedlots vigor tested with the $\mathrm{H}+2$ and $\mathrm{E} 4$ tests were planted in plastic flats randomized on greenhouse benches on the same day. The greenhouse temperature was $20^{\circ} \mathrm{C}$ in the evenings and $30^{\circ} \mathrm{C}$ from 0800 to $1600 \mathrm{~h}$ with natural light. All tests were initiated on the same day.

For the $\mathrm{E} 4$ and $\mathrm{H}+2$ tests (vigor tests) emerging through sand, seedlots were planted in plastic flats $(51 \mathrm{~cm}$ long by $36 \mathrm{~cm}$ wide by $10 \mathrm{~cm}$ deep). In each flat, an angle-iron tool was used to make a slight impression in the sand that extended the width of the flat and $0.25 \mathrm{~g}$ of seed was planted in the furrow (see Table 1 for the number of seeds per gram for each seedlot). After the seeds were planted, sand was placed over the seed to the desired depth and each seedlot and planting depth was replicated six times. Seedlings were counted for $21 \mathrm{~d}$ after planting. The emergence percentage was calculated by dividing the number of emerged seedlings by the number of seeds planted for each seedlot and multiplying the product by 100 .
Data collected for the PLS, NP, and P tests were the number of seeds per gram and number of germinated seeds (both root and shoot), whereas data for the $\mathrm{H}, \mathrm{E} 4$, and $\mathrm{H}+2$ tests were number of seeds per gram and number of seedlings emerged after $21 \mathrm{~d}$. Data from the germination and emergence tests were used to calculate seeding rates for the field trials based on the actual number of germinated or emerged seeds per gram. Seeds were packaged for field trial planting based on the number of germinated or emerged seedlings for each seedlot and seed quality test. Field trials were seeded to determine which seed quality test was the best predictor of switchgrass field establishment.

\section{Field Trials}

Each seedlot and seed quality evaluation test combination was planted in the field at 200 PLS or SETs $\mathrm{m}^{-2}$ in 1.5 -m-wide by 4 -m-long plots in rows spaced $15 \mathrm{~cm}$ apart at the University of Nebraska Agricultural Research and Development Center near Mead, NE. Field sites were planted in 2002 and 2003 to evaluate treatments across environments. Site 1 was seeded on 6 June 2002 on a Tomek silt loam soil (a fine, smectitic, mesic Pachic Argiudoll) with 0 to $2 \%$ slope. Sites 2 and 3 were adjacent, with Site 2 seeded on 28 May 2003 and Site 3 seeded on 27 June 2003 on Sharpsburg silty clay loam soils (fine, smectitic, mesic Typic Argiudolls). Switchgrass plots were planted with a no-till plot drill (Hege Inc., Waldenburg, Germany) that had seven disk openers on 15 -cm centers into a clean, firm seedbed that was disked, harrowed, and cultipacked within $14 \mathrm{~d}$ before planting. The seeding depth was $1.3 \mathrm{~cm}$. The plot drill was a cone-type drill, which plants all the preweighed seed placed in the rotating seed chamber in the exact length of a plot (Vogel, 1978) so seeding rates were exact. Experimental units were four replicates of each seedlot and seed quality test combination, arranged as a completely random design with a factorial arrangement of treatments. Field seeding rate was standardized at 200 PLS or SET m ${ }^{-2}$ (34 seeds $\mathrm{m}^{-1}$ of row) for each seedlot and seed quality test.

Herbicides applied immediately after planting were atrazine [Aatrex 4L; 6-chloro- $N$-ethyl- $N^{\prime}$-(1-methylethyl)-1,3,5triazine-2,4-diamine] at $2.2 \mathrm{~kg}$ a.i. $\mathrm{ha}^{-1}$ plus quinclorac (Paramount; 3,7-dichloro-8-quinolinecarboxylic acid) at $560 \mathrm{~g}$ a.i. $\mathrm{ha}^{-1}$ (Mitchell et al., 2010a). Herbicide spray solutions were applied with a tractor-mounted sprayer to deliver $190 \mathrm{~L} \mathrm{ha}^{-1}$. No additional treatments were applied to plots during the establishment year. The plots were fertilized with 
$67 \mathrm{~kg} \mathrm{~N} \mathrm{ha}^{-1}$ in the year after planting on 23 Apr. 2003 for Site 1 and 19 Apr. 2004 for Sites 2 and 3.

The number of seedlings per meter of row and seedling frequency of occurrence was used as measurements of establishment, and biomass yield was collected to measure productivity. A frequency grid, as described previously, was used to determine the frequency of occurrence. The number of seedlings per meter of row was determined from three rows in each plot in July, 30 to $45 \mathrm{~d}$ after planting. These data were used to calculate an establishment index, which is the ratio of the number of seeds emerged in the field relative to the number of germinable or emerging seeds planted. Before harvest in late autumn after a killing frost, the length of each plot was trimmed to $3 \mathrm{~m}$. Switchgrass biomass yield was determined on 7 Nov. 2002 and 7 Aug. 2003 for Site 1, 14 Nov. 2003 and 2 Aug. 2004 for Site 2, and 14 Nov. 2003 and 3 Aug. 2004 for Site 3. Consequently, harvests occurred about 5 and 14 mo after planting. Plots were harvested by cutting and weighing a $0.9 \mathrm{~m}$ wide by $3 \mathrm{~m}$ long swath from each subplot using a flail-type plot harvester (Carter Mfg., Brookston, IN) with a cutting height of $10 \mathrm{~cm}$. Before harvest, random subsamples were hand collected from each subplot, weighed, dried at $50^{\circ} \mathrm{C}$ for $72 \mathrm{~h}$ in a forced-air oven, and reweighed to determine the biomass dry matter concentration. The mean dry matter concentration of the subsamples was used to adjust biomass yields to oven-dry weights. Switchgrass frequency of occurrence (\%) was measured with a frequency grid (Vogel and Masters, 2001) immediately after both harvests.

In spring before switchgrass emergence, residue on the plots was removed by burning or moving. Broadleaf weeds were controlled during the year after planting with $1.1 \mathrm{~kg}$ a.i. ha ${ }^{-1}$ of 2,4-D low volatile ester [isocetyl (2-ethylexyl) ester of 2,4-dichlorophenoxyacetic acid] broadcast applied in a total spray volume of $190 \mathrm{~L} \mathrm{ha}^{-1}$ over the entire plot area at each site.

Data were analyzed separately for each site as a completely random design using the GLM procedure in SAS (SAS Institute, 1990). Seedlots were considered random effects. The stand frequency of occurrence data (\%) were transformed using the arcsine transformation for the ANOVA. Results from ANOVA for arcsine-transformed data were similar to those obtained using untransformed percentages so untransformed treatment means are reported.

\section{RESULTS AND DISCUSSION}

Perennial grass field establishment depends on adequate and timely precipitation. Annual precipitation at Mead was 647 $\mathrm{mm}$ in 2002 and $651 \mathrm{~mm}$ in 2003, both below the 30-yr average of $695 \mathrm{~mm}$ (Fig. 1). Although total precipitation in 2002 and 2003 was similar to the 30 -yr average $(-7 \%)$, the precipitation distribution varied across years. Mead received $410 \mathrm{~mm}$ of precipitation from planting until harvest (June-October) in 2002, $20 \mathrm{~mm}$ greater than the 30-yr average (Fig. 1). Precipitation in June, July, and September, however, was 55\% less than the long-term mean, while August received $210 \mathrm{~mm}$ of precipitation, 2.4 times the long-term average. In 2003, $305 \mathrm{~mm}$ of precipitation fell from June through October, $21 \%$ less than the long-term average. From June through October, only June and September exceeded the long-term monthly mean.

The number of seeds per gram was different $(P<0.05)$ across seedlots and ranged from 473 to 702 , with smaller seeds on
2002 שב $2003-30-y$ Mean

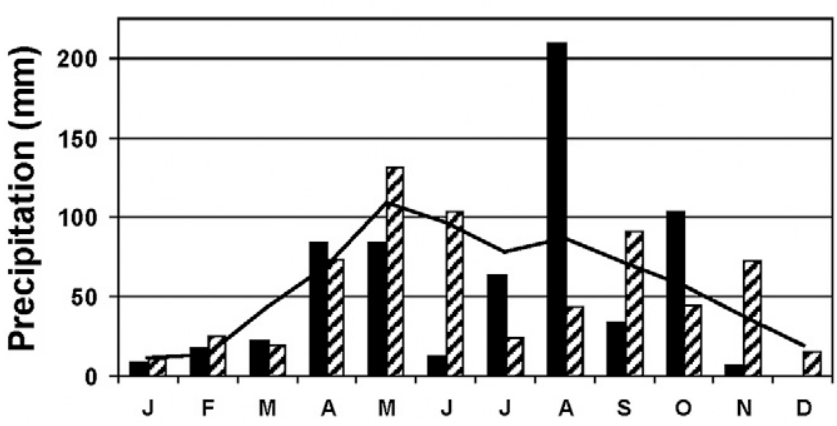

Fig. I. The 30-yr mean precipitation and monthly precipitation in $\mathbf{2 0 0 2}$ and 2003 for the University of Nebraska Agricultural Research and Development Center near Mead, NE. Total annual precipitation was 58 and $53 \mathrm{~mm}$ below the long-term average in 2002 and 2003, respectively.

average (more seeds per gram) in 2003 (Table 2). Seedlot germination was different $(P<0.05)$ and ranged from 7.9 to $93.7 \%$ (Table 2). Based on treatment means, there was no difference in germination for seedlots treated with no prechill, prechill, and heat in 2002; however, prechilled seedlots had the greatest germination in 2003 (Table 2). For Seedlot 12169, seeds germinated or emerged per gram of seed and the germination percentage declined from 2002 to 2003 for all tests, especially tests including heat. Seedlot 12169 was used both years, which allowed comparison of the effect of seed age. For Seedlot 12169 treated with heat, germination declined from 66\% in 2002 to $21 \%$ in 2003 , indicating that, as expected, as switchgrass seedlots age, they are more susceptible to injury when exposed to germination tests that include heat.

The SET- and PLS-based planting rate treatments resulted in significant differences in establishment and biomass 5 and 14 mo after planting in 2002 (Table 3). Field planting rate treatments based on SET including E4, NP, and P seed treatments resulted in the most seedlings per meter of row, whereas treatments based on applied heat resulted in the least number of seedlings per meter of row. Planting rates based on SET heat treatments resulted in $22 \%$ fewer seedlings per meter of row than the mean of the other treatments. Biomass 5 mo after planting was greatest for seeding rate treatments based on the E4 and P SETs (Table 3). Biomass yields 14 mo after planting were similar for all treatments except seeding rates based on the $\mathrm{H}+2$ treatment, which was less than NP but similar to all other treatments (Table 3).

Switchgrass seed quality tests resulted in differences in the frequency of occurrence 5 mo after planting in 2002 (Table 4). Planting rates based on E4 and P seed treatments both had frequencies of occurrence $>50 \%$ when averaged across all seedlots and ranked first or second for each of the 10 seedlots (Table 4). In the Great Plains, stands with grass frequencies of occurrence of $50 \%$ or greater can be classified as fully successful, grass frequencies of 25 to $50 \%$ indicate adequate stands, and grass frequencies of $<25 \%$ are regarded as marginal or unacceptable and may require reestablishment (Vogel and Masters, 2001). When averaged across all seedlots, all treatments were fully successful, with frequencies of occurrence exceeding 40\% (Table 4). Only Seedlot 91101, which had the lowest germination rate 
Table 2. Number of seeds per gram, seed establishment test seedlings germinated or emerged per gram of seed, and Association of Official Seed Analysts (AOSA) germination percentages (germinated seeds per 100 seeds) for 10 switchgrass seedlots evaluated in greenhouse trials using no prechill (NP), prechill (P), heat stress $(H)$, emergence through $4 \mathrm{~cm}$ of sand (E4), and heat stress plus emergence through $2 \mathrm{~cm}$ of sand $(\mathrm{H}+2)$ in 2002 and 2003.

\begin{tabular}{|c|c|c|c|c|c|c|c|c|c|c|}
\hline \multirow[b]{2}{*}{ Cultivar } & \multirow[b]{2}{*}{ Seedlot } & \multirow[b]{2}{*}{ Seeds } & \multicolumn{5}{|c|}{ Seeds germinated or emerged } & \multicolumn{3}{|c|}{ AOSA germination } \\
\hline & & & NP & $\mathbf{P}$ & $\mathbf{H}$ & E4 & $\mathbf{H}+\mathbf{2}$ & NP & $\mathbf{P}$ & $\mathbf{H}$ \\
\hline & & no. $g^{-1}$ & \multicolumn{5}{|c|}{ no. $g^{-1}$ of seed } & \multicolumn{3}{|c|}{$\%$} \\
\hline \multicolumn{11}{|c|}{$\underline{2002}$} \\
\hline Sunburst & 2199 & 552 & 375 & 445 & 476 & 304 & 413 & 68.1 & 83.1 & 83.8 \\
\hline Sunburst & 2221 & 507 & 447 & 455 & 439 & 341 & 429 & 85.3 & 90.3 & 88.7 \\
\hline Sunburst & 98063 & 481 & 422 & 426 & 408 & 355 & 403 & 87.1 & 89.1 & 84.6 \\
\hline Cave-in-Rock & 12169 & 652 & 456 & 423 & 436 & 391 & 457 & 70.0 & 66.0 & 65.9 \\
\hline Cave-in-Rock & 1712 & 473 & 399 & 438 & 407 & 387 & 419 & 84.6 & 92.8 & 85.7 \\
\hline Shawnee & 2061 & 662 & 357 & 462 & 339 & 269 & 419 & 53.6 & 71.7 & 50.1 \\
\hline Trailblazer & 2243 & 526 & 464 & 504 & 491 & 440 & 485 & 90.3 & 93.7 & 93.5 \\
\hline Trailblazer & 91149 & 702 & 386 & 300 & 405 & 242 & 331 & 55.9 & 42.5 & 57.4 \\
\hline Trailblazer & 7771 & 525 & 299 & 285 & 290 & 226 & 286 & 57.1 & 55.1 & 54.5 \\
\hline Trailblazer & 91101 & 482 & 129 & 40 & 129 & 75 & 93 & 26.7 & 7.9 & 27.4 \\
\hline Mean & & 556 & 373 & 378 & 382 & 303 & 374 & 67.9 & 69.2 & 69.2 \\
\hline $\operatorname{LSD}(0.05)$ & & 25 & . & . & -19 & & & . & -3.6 & \\
\hline \multicolumn{11}{|c|}{$\underline{2003}$} \\
\hline Sunburst & 2275 & 513 & 302 & 443 & 415 & 229 & 370 & 59.5 & 86.0 & 80.4 \\
\hline Sunburst & 2276 & 537 & 249 & 442 & 366 & 226 & 365 & 46.3 & 81.0 & 69.7 \\
\hline Cave-in-Rock & 2277 & 529 & 272 & 286 & 150 & 183 & 105 & 51.8 & 53.8 & 28.2 \\
\hline Trailblazer & 2278 & 622 & 487 & 485 & 477 & 388 & 396 & 74.9 & 82.5 & 76.1 \\
\hline Trailblazer & 2279 & 657 & 415 & 482 & 469 & 252 & 379 & 60.3 & 75.8 & 72.8 \\
\hline Trailblazer & 2280 & 618 & 450 & 475 & 484 & 264 & 420 & 72.3 & 76.5 & 72.3 \\
\hline Trailblazer & 2289 & 666 & 260 & 309 & 228 & 136 & 157 & 39.0 & 45.7 & 35.3 \\
\hline Shawnee & 2290 & 677 & 192 & 514 & 317 & 99 & 212 & 28.7 & 71.0 & 49.3 \\
\hline Shawnee & 2291 & 686 & 371 & 391 & 448 & 321 & 371 & 53.6 & 55.4 & 67.8 \\
\hline Cave-in-Rock & 12169 & 689 & 437 & 421 & 139 & 261 & $|2|$ & 66.4 & 55.8 & 20.9 \\
\hline Mean & & 619 & 344 & 425 & 349 & 236 & 290 & 55.3 & 68.4 & 58.0 \\
\hline $\operatorname{LSD}(0.05)$ & & 31 & 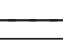 & 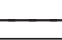 & -28 & & 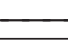 & 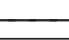 & -2.1 & 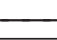 \\
\hline
\end{tabular}

Table 3. Mean switchgrass seedlings per meter of row $\sim 30 \mathrm{~d}$ after planting, aboveground biomass dry matter (DM) 5 mo after planting, and aboveground biomass DM 14 mo after planting at Site I, a field site seeded in 2002 near Mead, NE, using planting rates based on five seedlot establishment tests (SETs) averaged across 10 seedlots. A seeding rate of 200 germinated or emerged seeds $\mathrm{m}^{-2}$ was used, with the amount of seed planted dependent on the results of each specific SET.

\begin{tabular}{|c|c|c|c|}
\hline $\begin{array}{c}\text { Seed } \\
\text { quality test } \dagger\end{array}$ & Seedlings & $\begin{array}{l}\text { Biomass } 5 \text { mo } \\
\text { after planting }\end{array}$ & $\begin{array}{l}\text { Biomass I } 4 \text { mo } \\
\text { after planting }\end{array}$ \\
\hline & no. $\mathrm{m}^{-1}$ of row & $\longrightarrow M$ & $\mathrm{ha}^{-1}$ \\
\hline NP & 15.3 & $\mathrm{I} .45$ & 11.28 \\
\hline$P$ & 14.9 & 1.70 & 10.91 \\
\hline $\mathrm{H}$ & 12.5 & 1.39 & $|0.5|$ \\
\hline E4 & 18.0 & 1.82 & 10.94 \\
\hline $\mathrm{H}+2$ & 12.5 & 1.32 & 10.08 \\
\hline $\operatorname{LSD}(0.05)$ & 4.2 & 0.33 & 0.86 \\
\hline
\end{tabular}

$\dagger N P$, no prechill; $P$, prechill; $H$, heat stress; E4, emergence through $4 \mathrm{~cm}$ of sand; $\mathrm{H}+2$, heat stress plus emergence through $2 \mathrm{~cm}$ of sand.
Table 4. Frequency of occurrence of switchgrass seedlings 5 mo after field planting in $\mathbf{2 0 0 2}$ at Site I near Mead, NE, for 10 seedlots planted using rates based on five seedlot establishment tests (SETs). A seeding rate of 200 germinated or emerged seeds $\mathrm{m}^{-2}$ of plot area was used, with the amount of seed planted dependent on the results of each specific SET (NP, no prechill; $P$, prechill; $H$, heat stress; E4, emergence through $4 \mathrm{~cm}$ of sand; $\mathrm{H}+2$, heat stress plus emergence through $2 \mathrm{~cm}$ of sand).

\begin{tabular}{lcccccc}
\hline & & \multicolumn{5}{c}{ Frequency of occurrence } \\
\cline { 3 - 7 } \multicolumn{1}{c}{ Cultivar } & Seedlot & NP & P & H & E4 & H+2 \\
\cline { 3 - 7 } Cave-in-Rock & 1712 & 62 & 58 & 70 & 66 & 57 \\
Shawnee & 2061 & 49 & 49 & 68 & 70 & 60 \\
Sunburst & 2199 & 44 & 48 & 46 & 37 & 43 \\
Sunburst & 2221 & 52 & 69 & 42 & 66 & 71 \\
Trailblazer & 2243 & 73 & 69 & 63 & 64 & 40 \\
Trailblazer & 7771 & 27 & 36 & 32 & 35 & 35 \\
Cave-in-Rock & 12169 & 39 & 46 & 32 & 57 & 46 \\
Trailblazer & 91101 & 19 & 46 & 21 & 20 & 19 \\
Trailblazer & 91149 & 55 & 45 & 49 & 76 & 49 \\
Sunburst & 98063 & 61 & 42 & 54 & 66 & 45 \\
Mean & & 48 & 51 & 48 & 56 & 47 \\
LSD(0.05) & & & & 7 & & \\
\hline
\end{tabular}


for any seedlot evaluated (7.9\%), did not have adequate stands $(<25 \%)$ when averaged across seedlot treatments, indicating that it may not be possible to overcome establishment difficulties associated with very low quality seedlots even by using SET-based planting rates.

In 2003, the perennial grassland standard PLS seedlot evaluation test (Table 1) was incorporated into two field sites to compare with the other seedlot tests. In general, the standard PLS method for determining field planting rates was a relatively poor predictor of field establishment as indicated by seedlings per meter of row and switchgrass frequency of occurrence (Table 5). For eight of the 10 seedlots evaluated in 2003, the PLS-based planting rate treatment averaged the fewest (6.0) number of seedlings per meter of row $30 \mathrm{~d}$ after planting, whereas basing seedlot seeding rates on emergence through $4 \mathrm{~cm}$ of sand averaged the most (20.0), with more than three times as many seedlings, and was greatest for seven of the 10 seedlots (Table 5). The same trend continued through the end of the first and second growing seasons after planting. The mean plant frequency of occurrence 5 mo after seeding was least for the PLS method (22.8\%) and greatest for seeding rates based on E4 (46.3\%; Table 5). The mean plant frequency of occurrence 14 mo after seeding was least for the PLS method (26.8\%) and greatest for seeding rates based on E4 (45.7\%; Table 5). Interestingly, the mean for all seedlot treatments increased in frequency of occurrence from 5 to 14 mo after planting, except E4, which declined

Table 5. Effects of seedlot establishment test (SET) based planting rates and switchgrass seedlots on seedlings per meter of row, frequency of occurrence 5 mo after planting, and frequency of occurrence 14 mo after planting at Site 2 seeded in 2003 near Mead, NE, using SETs including pure live seed (PLS), no prechill (NP), prechill (P), heat stress (H), emergence through $4 \mathrm{~cm}$ of sand (E4), and heat stress plus emergence through $2 \mathrm{~cm}$ of sand $(\mathrm{H}+2)$.

\begin{tabular}{|c|c|c|c|c|c|c|c|}
\hline Cultivar & Seedlot & PLS & NP & $\mathbf{P}$ & $\mathbf{H}$ & E4 & $\mathrm{H}+2$ \\
\hline \multicolumn{8}{|c|}{ Seedlings, no. $\mathrm{m}^{-1}$ of row } \\
\hline Sunburst & 2275 & 10.3 & 14.3 & 12.5 & 14.3 & 23.8 & 6.3 \\
\hline Sunburst & 2276 & 4.8 & 21.5 & 8.3 & 18.5 & 27.5 & 14.8 \\
\hline Cave-in-Rock & 2277 & 1.5 & 3.8 & 10.5 & 23.0 & 13.3 & 23.8 \\
\hline Trailblazer & 2278 & 5.5 & 19.3 & 16.8 & 8.3 & 10.8 & 23.3 \\
\hline Trailblazer & 2279 & 11.8 & 10.5 & 6.8 & 19.5 & 25.3 & 17.3 \\
\hline Trailblazer & 2280 & 8.8 & 19.3 & 12.3 & 17.0 & 28.5 & 22.8 \\
\hline Trailblazer & 2289 & 4.0 & 14.5 & 10.3 & 11.0 & 25.0 & 18.0 \\
\hline Shawnee & 2290 & 2.5 & 13.5 & 2.8 & 6.3 & 20.5 & 20.0 \\
\hline Shawnee & 2291 & 7.0 & 13.3 & 13.0 & 13.8 & 16.0 & 6.3 \\
\hline CIR & 12169 & 3.5 & 4.3 & 11.0 & 17.0 & 9.5 & 27.3 \\
\hline Mean & & 6.0 & 13.4 & 10.4 & 14.9 & 20.0 & 18.0 \\
\hline $\operatorname{LSD}(0.05)$ & & & & & - & 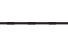 & \\
\hline \multicolumn{8}{|c|}{ Frequency of occurrence 5 mo after planting, $\%$} \\
\hline Sunburst & 2275 & 37.5 & 42.5 & 34.5 & 42.0 & 45.0 & 35.5 \\
\hline Sunburst & 2276 & 15.5 & 48.5 & 37.0 & 38.5 & 46.5 & 48.0 \\
\hline Cave-in-Rock & 2277 & 17.5 & 34.0 & 28.5 & 53.5 & 48.0 & 44.0 \\
\hline Trailblazer & 2278 & 22.5 & 42.0 & 38.5 & 30.0 & 38.3 & 50.5 \\
\hline Trailblazer & 2279 & 34.0 & 34.0 & 27.0 & 36.5 & 49.5 & 34.0 \\
\hline Trailblazer & 2280 & 26.5 & 47.0 & 40.5 & 39.5 & 55.0 & 42.0 \\
\hline Trailblazer & 2289 & 12.5 & 35.0 & 33.0 & 53.5 & 56.5 & 41.5 \\
\hline Shawnee & 2290 & 16.0 & 40.5 & 18.5 & 25.0 & 58.5 & 40.0 \\
\hline Shawnee & 2291 & 29.5 & 36.0 & 43.0 & 30.0 & 35.5 & 31.5 \\
\hline $\mathrm{CIR}$ & 12169 & 16.0 & 19.5 & 22.0 & 47.5 & 30.0 & 54.0 \\
\hline Mean & & 22.8 & 37.9 & 32.3 & 39.6 & 46.3 & 42.1 \\
\hline $\operatorname{LSD}(0.05)$ & & & & - & 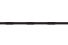 & & \\
\hline \multicolumn{8}{|c|}{ Frequency of occurrence 14 mo after planting, $\%$} \\
\hline Sunburst & 2275 & 30.3 & 31.3 & 23.8 & 32.3 & 45.8 & 35.3 \\
\hline Sunburst & 2276 & 20.0 & 43.8 & 29.0 & 50.0 & 47.0 & 45.5 \\
\hline Cave-in-Rock & 2277 & 25.3 & 37.5 & 28.5 & 56.3 & 53.8 & 56.3 \\
\hline Trailblazer & 2278 & 29.3 & 47.0 & 49.8 & 34.0 & 39.5 & 64.3 \\
\hline Trailblazer & 2279 & 40.3 & 39.5 & 39.0 & 38.3 & 54.5 & 35.0 \\
\hline Trailblazer & 2280 & 26.5 & 53.3 & 49.0 & 43.8 & 51.5 & 49.8 \\
\hline Trailblazer & 2289 & 19.0 & 47.0 & 32.3 & 54.5 & 47.0 & 40.0 \\
\hline Shawnee & 2290 & 23.3 & 55.3 & 17.5 & 24.5 & 41.8 & 30.8 \\
\hline Shawnee & 2291 & 31.5 & 33.8 & 41.8 & 33.0 & 45.0 & 27.5 \\
\hline CIR & 12169 & 22.5 & 23.0 & 29.0 & 44.5 & 31.3 & 43.5 \\
\hline Mean & & 26.8 & 41.1 & 34.0 & $4 I .1$ & 45.7 & 42.8 \\
\hline $\operatorname{LSD}(0.05)$ & & & & & & & \\
\hline
\end{tabular}




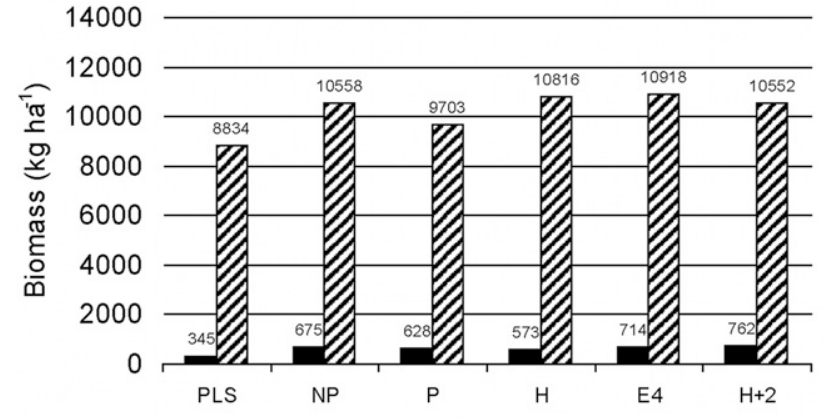

Site 3 Germination/Emergence Method

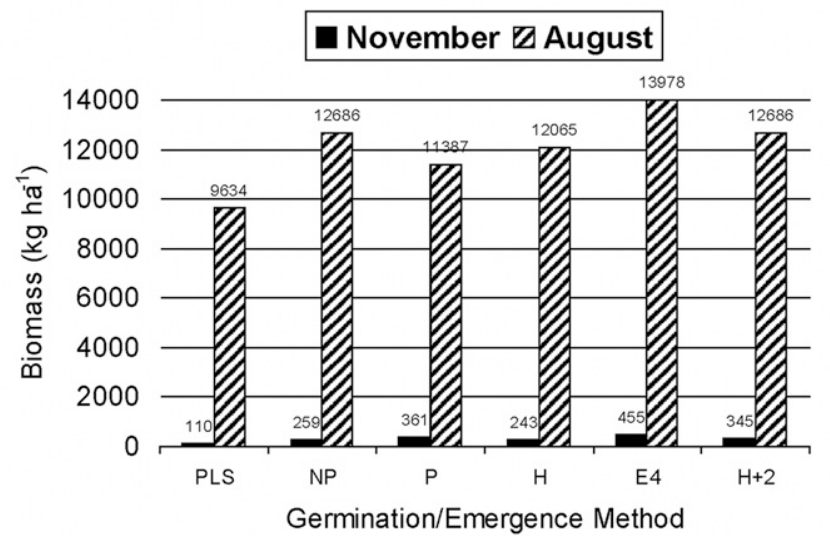

Fig. 2. Seedlot establishment test (SET) based seeding rate treatment effects on switchgrass aboveground biomass dry matter (DM) in $2003 \mathbf{4}$ or $\mathbf{5}$ mo after planting and aboveground biomass DM in 2004 I3 or 14 mo after planting at two field sites (Sites 2 and 3) seeded on 28 May and 27 June in 2003 near Mead, NE. Treatments were: PLS, pure live seed; NP, no prechill; $P$, prechill; $H$, heat stress; E4, emergence through $4 \mathrm{~cm}$ of sand; and $\mathrm{H}+2$, heat stress plus emergence through $2 \mathrm{~cm}$ of sand. Fisher's protected LSD $(0.05)$ values at Site 2 were 325 and $1152 \mathrm{~kg} \mathrm{ha}^{-1}$ for the harvests conducted 5 and 14 mo after planting, respectively. Fisher's protected $\operatorname{LSD}_{(0.05)}$ values at Site 3 were 170 and $1173 \mathrm{~kg} \mathrm{ha}^{-1}$ for the harvests conducted 4 and 13 mo after planting, respectively.

slightly. Clearly, standardizing seedlot seeding rates based on germination and emergence tests using the actual number of seeds per gram was a better predictor of establishment than the standard PLS method.

There were significant SET- or PLS-based seeding rate treatment effects on biomass yield for both sites seeded in 2003 (Fig. 2). Plots seeded in 2003 had limited biomass production in the seeding year, with biomass ranging from 110 to $760 \mathrm{~kg}$ $\mathrm{ha}^{-1}$ by the first killing frost (Fig. 2), probably a response to the limited precipitation in July and August after seeding in 2003 (Fig. 1). It would not be economically feasible to harvest this biomass in a bioenergy production system. By 13 to $14 \mathrm{mo}$ after seeding, however, treatment differences were prominent and biomass yield ranged from 8800 to $14,000 \mathrm{~kg} \mathrm{ha}^{-1}$. Stands with seeding rates based on PLS produced the least biomass in 2003 and 2004 at both sites and produced 2000 to $4300 \mathrm{~kg} \mathrm{ha}^{-1}$ less biomass in 2004 than the SET-based seeding rates based on E4. Switchgrass frequency of occurrence immediately after harvest was greatest for E4, with switchgrass stand frequencies of $64 \%$ 14 mo after planting, exceeding the PLS stand frequencies of $41.1 \%$ by $>50 \%$. There was a distinct yield and frequency of

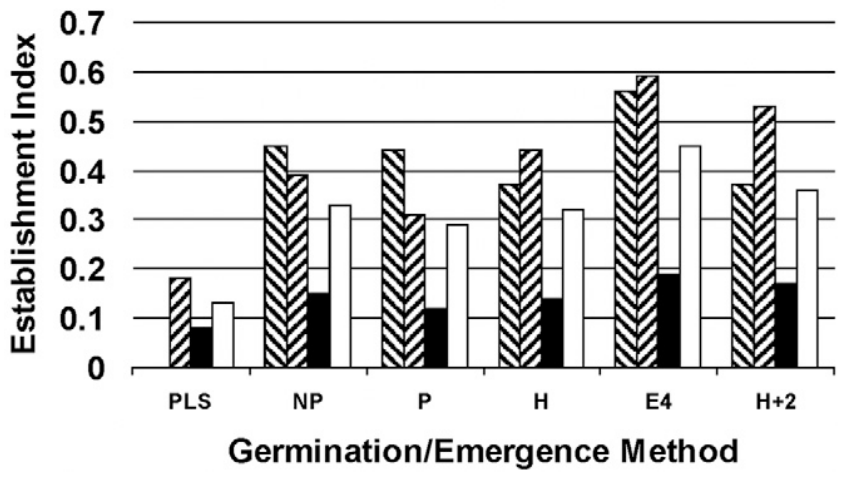

Fig. 3. Establishment index for 20 switchgrass seedlots established using seeding rates based on different seedlot establishment tests for three field trials in 2002 and 2003 near Mead, NE. The establishment index is the ratio of the number of seeds emerged in the field relative to the number of germinable or emerging seeds planted. Treatments included: PLS, pure live seed; NP, no prechill; P, prechill; $H$, heat stress; E4, emergence through $4 \mathrm{~cm}$ of sand; and $\mathrm{H}+2$, heat stress plus emergence through $2 \mathrm{~cm}$ of sand.

occurrence advantage to using planting rates based on a SET rather than using AOSA germination tests and a standard seeds per gram estimate (PLS). Additionally, these data demonstrate a strong relationship [yield $=93.6(5$-mo frequency $)+6780$; $\left.r^{2}=0.92\right]$ between switchgrass frequency 5 mo after planting and yield 14 mo after planting, indicating that switchgrass frequency at the end of the first growing season after planting is a predictor of future yield.

An establishment index, which is the ratio of the number of seeds emerged in the field relative to the number of germinable or emerging seeds planted, was used to compare how well each germination and emergence treatment translated into field establishment (Fig. 3). The establishment indices were relatively high for the germination and emergence methods in 2002 and Site 1 in 2003, except for the PLS method. Establishment indices were lower for Site 2 planted late (June 29) in 2003, indicating the need to plant switchgrass earlier in the spring with consistently cooler temperatures (Fig. 3). Little difference was observed for seeding rate treatments based on $\mathrm{P}, \mathrm{NP}$, and $\mathrm{H}$ SETs, with index values averaging $0.33,0.29$, and 0.32 , respectively. The mean index for the E4 SET, however, resulted in the greatest establishment index (0.45), which was $25 \%$ greater than the H+2 SET and 3.5 times greater than for PLS. These index values represent a clear quantification of the improvement in establishment that can be achieved by using SETs that address seed quality characteristics in addition to purity and germination when determining seeding rates.

\section{Potential Impact}

Basing switchgrass seeding rates on SETs that include stress components to evaluate vigor, such as emergence through $4 \mathrm{~cm}$ of sand, resulted in switchgrass stands with greater seedling density and greater biomass. Using current standard PLS procedures for determining the seeding rate $\left(\mathrm{kg} \mathrm{ha}^{-1}\right)$ resulted in marginally acceptable stand frequencies for the first two growing seasons after seeding and limited biomass, and PLS was a poor predictor of field establishment. All five SET treatments 
that adjusted seeding rates based on the number of germinated or emerged seeds per gram of seed, however, resulted in stands that were fully acceptable, with stand frequencies $>50 \% 14$ mo after seeding. This research clearly demonstrates that improvements in stands and biomass yield can be achieved when seeding rates are based on tests that take into consideration the differences in the number of seeds per gram and seedling vigor in addition to germination and purity. A simple seedlot test such as $\mathrm{E} 4$ can provide significant benefits by improving both stands and initial biomass yields with little additional cost. The addition of an extra step in the seedlot evaluation process is supported by $\mathrm{E} 4$ having a 36\% greater establishment index than NP (Fig. 3). Although NP is a reliable test for characterizing seedlot germination, adding the additional stress test of E4 directly translates into improved seed lot establishment in the field. We recommend using a seedlot establishment test when seeding switchgrass for biomass production for bioenergy to reduce the risk of seeding failure, assure quality stands, and improve establishment and first post-establishment year biomass yields. Additionally, using SETs in marketing switchgrass seed may enable producers of premium quality seed to differentiate their seed from other, lower quality seed.

\section{REFERENCES}

Anderson, B., J.K. Ward, K.P. Vogel, M.G. Ward, H.J. Gorz, and F.A. Haskins. 1988. Forage quality and performance of yearlings grazing switchgrass strains selected for differing digestibility. J. Anim. Sci. 66:2239-2244.

Association of Official Seed Analysts. 2010a. AOSA rules for testing seeds. AOSA, Ithaca, NY.

Association of Official Seed Analysts. 2010b. Tetrazolium testing handbook. AOSA, Ithaca, NY.

Cosgrove, D. R., and M. Collins. 2003. Forage establishment. p. 239-261. In R.F Barnes et al. (ed.) Forages: An introduction to grassland agriculture. 6th ed. Vol. 1. Iowa State Univ. Press, Ames.

Hopkins, A.A., K.P. Vogel, and K.J. Moore. 1993. Predicted and realized gains from selection for in vitro dry matter digestibility and forage yield in switchgrass. Crop Sci. 33:253-258. doi:10.2135/cropsci1993.0011183X $003300020007 \mathrm{x}$

Martin, A.R., R.S. Moomaw, and K.P. Vogel. 1982. Warm-season grass establishment with atrazine. Agron. J. 74:916-920. doi:10.2134/agronj1982. $00021962007400050034 x$

Masters, R.A., S.J. Nissen, R.E. Gaussoin, D.D. Beran, and R.N. Stougaard. 1996. Imidazolinone herbicides improve restoration of Great Plains grasslands. Weed Technol. 10:392-403.

McLaughlin, S.B., and L.A. Kszos. 2005. Development of switchgrass (Panicum virgatum) as a bioenergy feedstock in the United States. Biomass Bioenergy 28:515-535.
McLaughlin, S.B., and M.E. Walsh. 1998. Evaluating the environmental consequences of producing herbaceous crops for bioenergy. Biomass Bioenergy 14:317-324.

Mitchell, R.B., K.P. Vogel, J. Berdahl, and R. Masters. 2010a. Herbicides for establishing switchgrass in the central and northern Great Plains. Bioenergy Res. 3:321-327. doi:10.1007/s12155-010-9084-4

Mitchell, R.B., K.P. Vogel, and G. Sarath. 2008. Managing and enhancing switchgrass as a bioenergy feedstock. Biofuels Bioproducts Biorefining 2:530-539. doi:10.1002/bbb.106

Mitchell, R.B., K.P. Vogel, M.R. Schmer, and D. Pennington. 2010b. Switchgrass for biofuel production. Available at extension.org/pages/Switchgrass_for_Biofuel_Production (verified 14 Jan. 2012). eXtension Initiative, Lincoln, NE.

Newman, P.R., and L.E. Moser. 1988. Grass seedling emergence, morphology, and establishment as affected by planting depth. Agron. J. 80: 383-387. doi:10.2134/agronj1988.00021962008000030001x

Perrin, R.K., K.P. Vogel, M.R. Schmer, and R.B. Mitchell. 2008. Farm-scale production cost of switchgrass for biomass. Bioenergy Res. 1:91-97. doi:10.1007/s12155-008-9005-y

Sanderson, M.A., R. Reed, S. McLaughlin, S. Wullschleger, B. Conger, D. Parrish, et al. 1996. Switchgrass as a sustainable bioenergy crop. Bioresour. Technol. 56:83-93. doi:10.1016/0960-8524(95)00176-X

Sarath, G., and R.B. Mitchell. 2008. Aged switchgrass seed lot's response to dormancy-breaking chemicals. Seed Technol. 30:7-16.

SAS Institute. 1990. SAS/STAT user's guide. Version 6. 4th ed. SAS Inst., Cary, NC.

Schmer, M.R., K.P. Vogel, R.B. Mitchell, L.E. Moser, K.M. Eskridge, and R.K. Perrin. 2006. Establishment stand thresholds for switchgrass grown as a bioenergy crop. Crop Sci. 46:157-161. doi:10.2135/cropsci2005.0264

Vogel, K.P. 1978. A simple method of converting rangeland drills to experimental plot seeders. J. Range Manage. 31:235-237. doi:10.2307/3897187

Vogel, K.P. 1987. Seeding rates for establishing big bluestem and switchgrass with preemergence atrazine applications. Agron. J. 79:509-512. doi:10.2134/agronj1987.00021962007900030021x

Vogel, K.P. 2002. The challenge: High quality seed of native plants to ensure establishment. Seed Technol. 24:9-15.

Vogel, K.P. 2004. Switchgrass. p. 561-588. In L.E. Moser et al. (ed.) Warmseason $\left(\mathrm{C}_{4}\right)$ grasses. Agron. Monogr. 45. ASA, CSSA, and SSSA, Madison, WI.

Vogel, K.P., H.J. Gorz, and F.A. Haskins. 1981. Divergent selection for in vitro dry matter digestibility in switchgrass. Crop Sci. 21:39-41. doi:10.2135/ cropsci1981.0011183X002100010011x

Vogel, K.P., and R.A. Masters. 2001. Frequency grid: A simple tool for measuring grassland establishment. J. Range Manage. 54:653-655. doi: $10.2307 / 4003666$

Vogel, K.P., G. Sarath, A.J. Saathoff, and R.B. Mitchell. 2010. Switchgrass. p. 341-380. In N.G. Halford and A. Karp (ed.) Energy crops. R. Soc. Chem., Cambridge, UK.

Wheeler, W.A., and D.D. Hill. 1957. Grassland seeds. D. Van Nostrand Co., Princeton, NJ. 